\title{
Seasonal patterns in water uptake for Medicago sativa grown along an elevation gradient with shallow groundwater table in Yanchi county of Ningxia, Northwest China
}

\author{
ZHU Lin ${ }^{1,2^{*}}$, ZHANG Huili ${ }^{3}$, GAO Xue ${ }^{1,2}$, QI Yashu ${ }^{3}$, XU Xing ${ }^{1,2}$ \\ ${ }^{1}$ State Key Laboratory Breeding Base of Land Degradation and Ecological Restoration of North-western China, Ningxia \\ University, Yinchuan 750021, China; \\ ${ }^{2}$ Key Laboratory for Restoration and Reconstruction of Degraded Ecosystem of North-western China, Ministry of Education, \\ Ningxia University, Yinchuan 750021, China; \\ ${ }^{3}$ Agricultural College, Ningxia University, Yinchuan 750021, China
}

\begin{abstract}
Lucerne (Medicago sativa L.) is a deep-rooted perennial leguminous forage with high evapo-transpiration rate exceeding the annual precipitation in semi-arid areas of Northwest China. Groundwater might be the potential water sources of lucerne in the area with shallow groundwater table. In this study, stable isotopic compositions of oxygen and hydrogen $\left(\delta^{18} \mathrm{O}\right.$ and $\left.\delta D\right)$ of different water sources and xylem sap were analyzed to determine the seasonal (April, June, July and August) and topographic (three slope positions) variations in water sources for lucerne growing in Ningxia eastern semi-arid area adjacent to Mu Us Desert characterized by shallow groundwater table. IsoSource software was used to calculate the probable contribution of different water sources to the total plant water uptake. Stomatal conductance, stem water potential, carbon isotope discrimination $\left(\Delta^{13} \mathrm{C}\right)$ of whole plant were also determined for evaluating the water status of lucerne growing at different slope positions. The results showed that soil water content increased as the elevation decreased. Oxygen compositions of soil water in the $0-40 \mathrm{~cm}$ profile fluctuated considerably. Soil water $\delta^{18} \mathrm{O}$ values in deep profile $(>3.5 \mathrm{~m})$ were similar to those in groundwater, implying the recharge of groundwater to this soil layer. Highest water utilization rate from deep soil profile (below $350 \mathrm{~cm}$ ) was recorded for lucerne grown at the slope position 1 (groundwater table depth of 3.5-3.9 m) in April, June and July. The lucernes at slope position 2 (groundwater table depth of 5.8-6.4 m) and slope position 3 (groundwater table depth 7.1-8.3 m) mostly used water from deep soil layers (below $350 \mathrm{~cm}$ ) during dry period, and turned to use water from superficial soil layer in wet period. Higher yield, $\Delta^{13} \mathrm{C}$ value of whole plant and stomatal conductance were observed for lucerne grown at the slope position 1 than those at other slope positions. These results indicated that groundwater is a significant water source for transpiration of lucerne grown in Ningxia semi-arid area with shallow groundwater table where lucerne grassland is suggested to be established so as to obtain better yield performance.
\end{abstract}

Keywords: lucerne; water uptake; groundwater table; oxygen and hydrogen isotopic compositions; evapo-transpiration

Citation: ZHU Lin, ZHANG Huili, GAO Xue, QI Yashu. 2016. Seasonal patterns in water uptake for Medicago sativa grown along an elevation gradient with shallow groundwater table in Yanchi county of Ningxia, Northwest China. Journal of Arid Land, 8(6): 921-934. doi: 10.1007/s40333-016-0017-8

${ }^{*}$ Corresponding author: ZHU Lin (E-mail: zhulinscience@126.com)

Received 2016-01-30; revised 2016-05-15; accepted 2016-05-20

(C) Xinjiang Institute of Ecology and Geography, Chinese Academy of Sciences, Science Press and Springer-Verlag Berlin Heidelberg 2016 
Lucerne (Medicago sativa L.), a summer-active legume, has been widely planted in the semi-arid region of the Loess Plateau in northern China for more than 2,000 years, because of its value for animal feed, reducing soil erosion and improving soil fertility/quality (Raza et al., 2013; Fan et al., 2014). However, the limitation of soil water in this semi-arid area restricts the yield performance of lucerne which has a high evapo-transpiration (ET) rate and deep roots, requiring more water than other crops (Blad and Rosenberg, 1976; Ward et al., 2002; Jia et al., 2009; Shen et al., 2009; Fan et al., 2014; Jia and Shao, 2014). Some studies conducted in the semi-arid Loess Plateau areas manifested that the actual ET of lucerne is more than precipitation during the growing season (Li and Zhang, 1991; Li and Huang, 2008; Fan et al., 2014). In Shenmu county, Shaanxi province, where average annual precipitation is $435 \mathrm{~mm}$, the average annual lucerne ET over 5 years was $491 \mathrm{~mm}$ during forage growing season (Fan et al., 2014). Li and Zhang (1991) reported that the ET of the lucerne grassland during the whole growth period in Sidunzi and Yanchi counties, was 312.6 $\mathrm{mm}$ in excess of the average annual precipitation $(291.5 \mathrm{~mm})$ in this area. Research conducted in Australia also indicated that lucerne could use at least $50 \mathrm{~mm}$ more water than annual pastures or crops (Dunin et al., 2001; Latta et al., 2001; Ridley et al., 2001). Therefore, in this semi-arid region, a long-term phase of lucerne could result in soil water deficits (Jia et al., 2006; Jia et al., 2009).

In water-limited environments, where evaporative demand exceeds precipitation and water tends to be unavailable in upper soil horizons, plants are likely to have deep roots and extract water from deep soil layers or groundwater (Romero-Saltos et al., 2005; West et al., 2008). Numerous researches that studied the water sources of several species using hydrogen or oxygen isotopic compositions have indicated the significant effect of groundwater on plant water balance and water use (Shafroth et al., 2000; Chimner and Cooper, 2004; Xu and Li, 2006; Eggemeyer et al., 2009; Rossatto et al., 2012; Wang et al., 2013; Soylu et al., 2014). Previous studies conducted in arid and semi-arid regions have indicated that groundwater is an important water source for plants due to the lack of reliable surface water resources (Yin et al., 2011; Wang et al., 2013). These findings were also reinforced by means of a process-based ecosystem model (Agro-IBIS) in the report of Soylu et al. (2014) who found a positive impact of shallow groundwater on the physiology and phenological development of maize.

Since there is no fractionation of oxygen isotope during root water uptake and transport to the stem for terrestrial plants (Dawson, 1993; Thorburn et al., 1993), stable isotopic composition of oxygen $\left(\delta^{18} \mathrm{O}\right)$ has been used as a natural tracer to determine the source of water extracted from soil by plant (Dawson and Ehleringer, 1993). Thus, the proportion of water taken up from these sources can be quantified by comparing the stable oxygen isotopic composition of stem water with those of potential water sources (Asbjornsen et al., 2008).

Published researches mainly touched on the yield, water use of lucerne grown in the semi-arid region with deep groundwater table. Little information about the utilization of groundwater by lucerne grown in the areas with shallow groundwater table is available. Lucerne had a root depth of $>5 \mathrm{~m}$ in two years' planting and the root length became $>10 \mathrm{~m}$ after five years' planting in China (Jia et al., 2006; Li and Huang, 2008; Shen et al., 2009). Elsewhere, lucerne has been reported to have a root depth of $>34 \mathrm{~m}$ (Bauder et al., 1978) and is able to utilize shallow groundwater.

In this work, the effect of topographic gradient (with different groundwater levels) on yield and physiological characters of lucerne was investigated in Beiwangjuan village adjacent to the southern $\mathrm{Mu}$ Us Desert characterized by shallow groundwater table. The depth of plant water uptake was estimated by comparing oxygen isotope ratios of plant stem water with soil water collected at different depths and groundwater. Vertical partitioning of soil water extracted by lucerne along the topographical gradient was estimated by inputting these data to a stable isotope mixing model. Carbon isotope discrimination, leaf stomatal conductance and stem water potential were measured for evaluating the water status of lucerne grown at different elevations. 


\section{Materials and methods}

\subsection{Study area}

The study was carried out at Beiwangjuan village $\left(37^{\circ} 52^{\prime} \mathrm{N}, 107^{\circ} 28^{\prime} \mathrm{E} ; 1,316-1,328 \mathrm{~m}\right.$ asl), Ningxia Hui autonomous region, China (Fig. 1). This experimental site is located at the transitional area between Loess Plateau and Ordos highland and neighbors to Mu Us Desert in the south. This area is characterized by gentle-slope upland with groundwater table ranging from 3 to $8 \mathrm{~m}$ (Zhang et al., 2009; Han et al., 2012; Wang et al., 2013). The climate is continental semi-arid temperate with a warm summer. The average annual precipitation is approximately $280 \mathrm{~mm}$ of which $70 \%$ falls from June to September. The potential annual ET is $2,710 \mathrm{~mm}$. Annual mean temperature is $7.5^{\circ} \mathrm{C}$. Maximum and minimum air temperatures are $34.9^{\circ} \mathrm{C}$ and $-24.2^{\circ} \mathrm{C}$, respectively. Annual frost-free period is $162 \mathrm{~d}$.

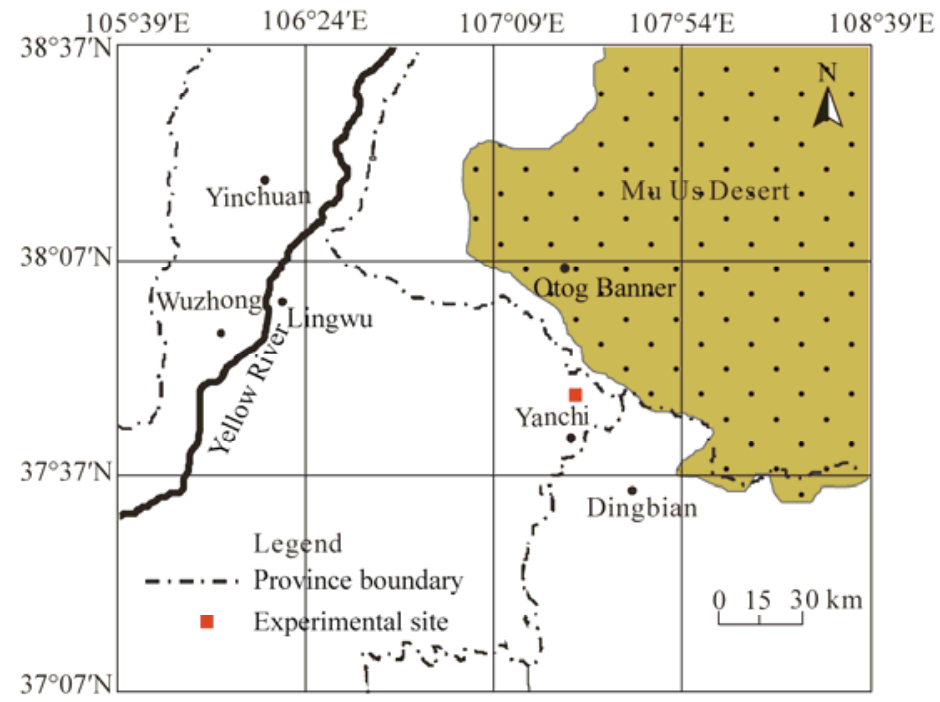

Fig. 1 Location of study area in the eastern region of Ningxia Hui autonomous region, Northwest China

We selected three plots growing 8-year-old lucerne in a gentle hilly area spanning an elevation gradient of about $11 \mathrm{~m}$. The three plots were nominated by GW1, GW2 and GW3 according to the groundwater depth along an elevating gradient. The lowest groundwater depth is about $3.7 \mathrm{~m}$ in GW1. Soil at GW1 is characterized by high clay fraction, while GW2 and GW3 contain more gravel or sand ingredients in soil profiles. Soil water content increases as the elevation decreases (Table 1) (Xu et al., 2008).

Table 1 Geographical information and soil physical property of the three sites

\begin{tabular}{|c|c|c|c|c|c|c|c|c|c|}
\hline Sampling & & Coordinate & $\begin{array}{c}\text { Groundwater } \\
\text { table }\end{array}$ & $\begin{array}{l}\text { Soil } \\
\text { depth }\end{array}$ & $\begin{array}{c}\text { Gravel } \\
>2.0 \mathrm{~mm} \\
\end{array}$ & $\begin{array}{c}\text { Sand } \\
0.2-0.02 \mathrm{~mm} \\
\end{array}$ & $\begin{array}{c}\text { Silt } \\
0.02-0.002 \mathrm{~mm} \\
\end{array}$ & $\begin{array}{c}\text { Clay } \\
<0.002 \mathrm{~mm} \\
\end{array}$ & $\begin{array}{c}\text { Soil water } \\
\text { content }\end{array}$ \\
\hline & $(\mathrm{m})$ & & $(\mathrm{m})$ & $(\mathrm{cm})$ & & & $(\%)$ & & \\
\hline \multirow{3}{*}{ GW1 } & \multirow{3}{*}{1,317} & & \multirow{3}{*}{$3.5-3.9$} & $0-20$ & - & 60.5 & 20.1 & 19.4 & 13.4 \\
\hline & & $\begin{array}{l}37^{\circ} 52.03^{\prime} \mathrm{N}, \\
107^{\circ} 28.04^{\prime} \mathrm{E}\end{array}$ & & $20-300$ & - & 49.1 & 22.4 & 28.5 & 11.8 \\
\hline & & & & $>300$ & - & 42.4 & 26.4 & 31.2 & 28.8 \\
\hline \multirow{3}{*}{ GW2 } & \multirow{3}{*}{1,324} & & \multirow{3}{*}{$5.8-6.4$} & $0-20$ & - & 77.5 & 11.9 & 10.6 & 11.3 \\
\hline & & $\begin{array}{l}37^{\circ} 52.01^{\prime} \mathrm{N}, \\
107^{\circ} 28.05^{\prime} \mathrm{E}\end{array}$ & & $20-300$ & 10.3 & 53.1 & 21.5 & 15.1 & 6.3 \\
\hline & & & & $>300$ & 5.1 & 72.3 & 9.5 & 13.1 & 23.6 \\
\hline \multirow{3}{*}{ GW3 } & \multirow{3}{*}{1,328} & & \multirow{3}{*}{$7.1-8.3$} & $0-20$ & - & 67.5 & 21.9 & 10.6 & 7.7 \\
\hline & & $\begin{array}{l}37^{\circ} 52.00^{\prime} \mathrm{N}, \\
107^{\circ} 28.09^{\prime} \mathrm{E}\end{array}$ & & $20-300$ & - & 63.3 & 25.5 & 11.2 & 7.5 \\
\hline & & & & $>300$ & - & 46.8 & 38.5 & 14.7 & 17.9 \\
\hline
\end{tabular}




\subsection{Soil parameters measurement}

Soil water content (mass ratio) was monitored on 28 April, 2 June, 19 July and 19 August 2013. Soil was sampled by an auger from 0 to $4.5 \mathrm{~m}$ depth at $0.2 \mathrm{~m}$ intervals, and repeated three times. Soil water content was determined by oven-drying and balance-weighing method. When soil was sampled for determining $\delta \mathrm{D}$ and $\delta^{18} \mathrm{O}$ and soil water content, an auger with detachable $0.5-\mathrm{m}$ steel tubes (Fig. 2) which can be assembled to $5 \mathrm{~m}$ in length was used. Groundwater monitoring well was drilled at GW1 where groundwater was sampled and groundwater table was observed periodically. Soil texture in different slope positions was measured based on Stockes' law.

$$
V=\frac{2}{9} g r^{2} \frac{\left(d-d_{1}\right)}{\eta} .
$$

Where $V$ is sedimentation speed of soil particle in suspension $(\mathrm{cm} / \mathrm{s}) ; g$ is acceleration of gravitation $\left(980 \mathrm{~cm} / \mathrm{s}^{2}\right) ; r$ is radius of soil particle $(\mathrm{mm}) ; d$ is density of soil particle $\left(\mathrm{g} / \mathrm{cm}^{3}\right) ; d_{1}$ is density of media $\left(\mathrm{g} / \mathrm{cm}^{3}\right) ; \eta$ is coefficient of viscosity $(\mathrm{g} /(\mathrm{cm} \cdot \mathrm{s}))$. Given the soil and media in this study, $d$ is $2.65 \mathrm{~g} / \mathrm{cm}^{3}, d_{1}$ is $1 \mathrm{~g} / \mathrm{cm}^{3}$ and $\eta$ of water is $1.005 \mathrm{~g} /(\mathrm{cm} \cdot \mathrm{s})$ at $20^{\circ} \mathrm{C}$. According to the height of flask and the radius of sand $(0.2-0.02 \mathrm{~mm})$, silt $(0.02-0.002 \mathrm{~mm})$ and clay $(<0.002 \mathrm{~mm})$, the sedimentation times of the three particles were figured out, i.e. $1 \mathrm{~min}, 1 \mathrm{~h}$ and $2 \mathrm{~h} \mathrm{at} 20^{\circ} \mathrm{C}$.

For measuring soil texture, air-dried soil was passed through a 2-mm sieve. The soil particles bigger than $2 \mathrm{~mm}$ were weighed by electronic scale, the proportion of gravel was then obtained by the ratio of mass of particles to total soil samples. Twenty grams sieved soil was filled in a porcelain bowl and immersed with distilled water $\left(20^{\circ} \mathrm{C}\right)$, then $0.5 \mathrm{~mol} / \mathrm{L} \mathrm{Na}_{2} \mathrm{C}_{2} \mathrm{O}_{4}$ was added. The suspension was ground by a grinding rod for $15 \mathrm{~min}$. The mud was poured into a $1 \mathrm{~L}$ flask and distilled water was added up to $1,000 \mathrm{~mL}$ in volume. The density of suspension was measured by hydrometer (TM-85, China) $1 \mathrm{~min}, 1 \mathrm{~h}$ and $2 \mathrm{~h}$ (nominated by reading1, reading2 and reading3, respectively). The proportions of different components were calculated by the following equations:

$$
\begin{gathered}
\text { Sand }=\frac{\text { mass }_{\text {sample }}-\text { reading } 1}{\text { mass }_{\text {sample }}} \times 100 \%, \\
\text { Silt }=\frac{\text { reading } 3-\text { reading } 2}{\text { mass }_{\text {sample }}} \times 100 \%, \\
\text { Clay }=\frac{\text { reading } 3}{\text { mass }_{\text {sample }}} \times 100 \% .
\end{gathered}
$$

\subsection{Sampling and isotopic analysis of stem and water sources}

Samples of groundwater, soil water from different depths and plant xylem were collected on 28 April, 2 June, 19 July and 19 August 2013. Groundwater was sampled from a monitoring well in GW1. Soil samples were collected in nine intervals $(0-20,20-40,40-80,80-150,150-220$, 220-270, 270-350, 350-400 and 400-450 cm) at GW2 and GW3 and in eight intervals (absence of $400-450 \mathrm{~cm}$ ) in GW1. Basal stem samples of five lucerne individuals were collected at random. During sampling, the epidermis of basal stem was stripped off and cut into pieces of five centimeters in length. Samples were sealed in glass vials with screw caps and wrapped with parafilm. Rain water samples were collected after each rain event from April to August with rain collectors installed in open sites near the study site. Samples of soil and stem were kept frozen at $-20^{\circ} \mathrm{C}$, while rainwater, well water and groundwater samples were stored at $4{ }^{\circ} \mathrm{C}$ until analysis for hydrogen and oxygen isotope compositions. For analyzing carbon isotope composition, 10 above-ground plants per slope position were collected at flowering stage before lucerne was cut. The samples were dried at $60^{\circ} \mathrm{C}$ for $48 \mathrm{~h}$ and ground to fine powder.

The water extraction from plant stems and soils as well as isotopic analyses were conducted at Forest Environment and Protection Institute, China Academy of Forestry Science. For analyzing $\delta \mathrm{D}$ and $\delta^{18} \mathrm{O}$, water in soil and stem was extracted using cryogenic vacuum distillation (Horton et 
al., 2003). $\mathrm{H}_{2} \mathrm{O}$ was split into $\mathrm{CO}$ and $\mathrm{H}_{2}$ in the presence of catalyst in FLASHEA 1112HT (Thermo Scientific, Germany) isotopic analyzer. DELTAV isotope ratio mass spectrometer (Thermo Scientific, Germany) was used to analyze compositions of $\mathrm{O}$ in $\mathrm{CO}$ and $\mathrm{H}$ in $\mathrm{H}_{2}$ for obtaining the ratios ${ }^{18} \mathrm{O} /{ }^{16} \mathrm{O}$ and ${ }^{2} \mathrm{H} /{ }^{1} \mathrm{H}$. Carbon isotope compositionn was determined on one milligram sample with Isotopic Ratio Mass Spectrometer (Model Thermo Finnigan, Bremen, Germany). The $\delta \mathrm{D}, \delta^{18} \mathrm{O}$ and $\delta \mathrm{C}$ values were expressed in parts per thousand (\%o) and expressed as:

$$
\delta^{18} \mathrm{O}, \delta \mathrm{D} \text { or } \delta \mathrm{C}=\left(\frac{R_{\text {sample }}}{R_{\text {standard }}}-1\right) \times 1000 .
$$

Where $R$ is the molar ratio of the heavy to light isotopes in the sample and appropriate standards. $R_{\text {sample, }}{ }^{2} \mathrm{H} /{ }^{1} \mathrm{H}$ for deuterium, ${ }^{18} \mathrm{O} /{ }^{16} \mathrm{O}$ for oxygen and ${ }^{13} \mathrm{C} /{ }^{12} \mathrm{C}$ for carbon; $R_{\text {standard, }}$ the Vienna standard mean ocean water (V-SMOW) for hydrogen and oxygen and Pee Dee Belemnite (PDB) carbonate for carbon.

Since the nine source endpoints measured from 0 to $450 \mathrm{~cm}$ soil profile were too many to operate for feasible solutions. Therefore, we combined the data of soil water $\delta \mathrm{D}$ and $\delta^{18} \mathrm{O}$ into three layers $(0-20,20-350$ and $350-450 \mathrm{~cm})$.

Carbon isotope discrimination $\left(\Delta^{13} \mathrm{C}\right)$ was calculated using the following formula (Farquhar et al., 1989):

$$
\Delta^{13} \mathrm{C}=\left(\frac{\delta_{a}-\delta_{p}}{1+\delta_{p}}\right) \times 1000 .
$$

Where $\delta_{p}$ is $\delta^{13} \mathrm{C}$ of sample and $\delta_{a}$, the $\delta^{13} \mathrm{C}$ of atmospheric $\mathrm{CO}_{2}$. On the PDB scale, atmospheric $\mathrm{CO}_{2}$ has a current deviation of approximately $-8 \%$.

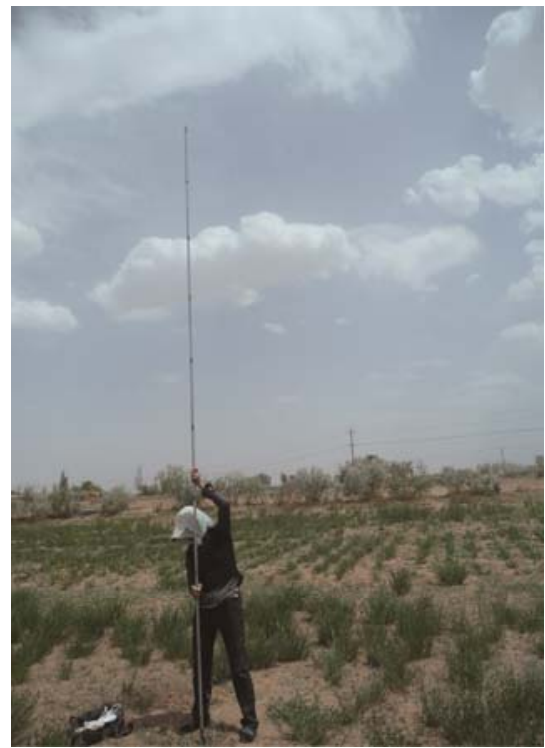

Fig. 2 The process of soil sampling with Luoyang shovel. For sampling soil in the depth profiles, a customized auger (traditionally, Luoyang shovel) with detachable $0.5-\mathrm{m}$ steel tubes which can be assembled to $5 \mathrm{~m}$ was employed.

\subsection{Measurements of leaf stomatal conductance and xylem water potentials}

While the soil samples were collected for analyzing hydrogen and oxygen compositions, leaf stomatal conductance $\left(\mathrm{g}_{\mathrm{s}}\right)$ and xylem water potentials were also measured. Leaf stomatal conductance was measured with a portable porometer (AP4, Delta-T, Cambridge, UK) at 10:00-11:30. The measurements were made on fully developed upper leaves for each slope position. Leaves were maintained at right angles to intercept solar radiation. Five measurements 
were made per slope position.

Predawn (Bar; $1 \mathrm{~h}$ before sunrise) and midday (Bar; 11:30-12:30) water potentials were measured with a pressure chamber (PMS Instrument Co., Albany, OR, USA). Water potential was determined on basal stem from five individuals randomly collected in each slope position.

\subsection{Statistical analysis}

The effects of slope position and sampling period on the measured agronomic and physiological characters were tested with factorial ANOVA analyses (GLM procedure of the SAS software package, SAS Institute, Cary, NC, USA), where the $P$-values were considered statistically significant at the 0.05 level.

For determining the fractional contribution of water sources to studied species, we used the IsoSource software (Phillips et al., 2005).

\section{Results}

\subsection{Rainfall distribution, atmosphere temperature in Beiwangjuan village}

As shown in Fig. 3, there was scarce rain event in March and April in Beiwwangjuan village. Rainfall events mainly took place in June and July. Totally, the rainfall from June to August was $173.7 \mathrm{~mm}$ which was normal year in Yanchi county. Generally, the mean temperature fit the single-peak curve. Lowest monthly mean temperature $\left(-5.9^{\circ} \mathrm{C}\right)$ was observed in January. August was the hottest $\left(22.9^{\circ} \mathrm{C}\right)$ month, followed by July $\left(22.0^{\circ} \mathrm{C}\right)$ and June $\left(21.8^{\circ} \mathrm{C}\right)$.

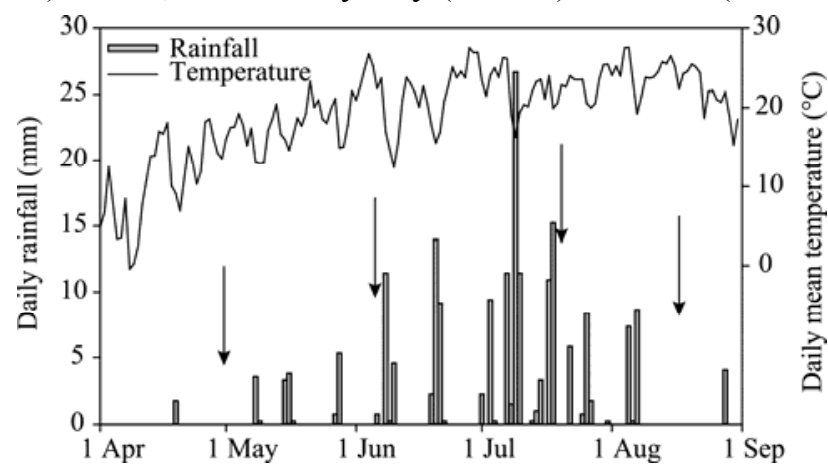

Fig. 3 Daily rainfall and mean temperature from April to September 2013. Arrow points to the date when soil water, groundwater, plant xylem sap were sampled.

\subsection{Isotopic signatures of plant xylem sap and water sources}

The oxygen and hydrogen compositions of rainfall water exhibited a decreasing tendency over time from April to July and increased to some extent in August. A plot of the $\delta \mathrm{D}$ versus $\delta^{18} \mathrm{O}$ values of rainfall water fell local meteoric water line (LMWL) in the arid Northwest China $\left(\delta \mathrm{D}=7.218 \delta^{18} \mathrm{O}+5.505\right)$ (Liu et al., 2012). The $\delta \mathrm{D}$ and $\delta^{18} \mathrm{O}$ values of groundwater, soil water and plant xylem sap fell to the right side of the LMWL with groundwater $\delta \mathrm{D}$ and $\delta^{18} \mathrm{O}$ plotting closer to the line. The coordinates $\left(\delta \mathrm{D}\right.$ versus $\left.\delta^{18} \mathrm{O}\right)$ of soil water from shallow layers were enriched (i.e. with higher isotopic composition and "enriched" in heavy isotopes) and were plotted far away from the line, indicating strong evaporation effect in our experiment site (Figs. 4 and 5). Plant xylem sap isotope compositions were significantly lower in GW1 (lowest slope position) in April, June and July than those of other two positions $(P<0.05)$ (Fig. 6).

\subsection{Isotopic signature of soil water and groundwater}

There was a significant difference in the $\delta^{18} \mathrm{O}$ signatures of soil water along the elevation gradient $(P<0.05)$. Soil water from the lower slope elevations was characterized by lower values of $\delta^{18} \mathrm{O}$, especially in June and July. Relatively negative $\delta 180$ values were recorded for groundwater in all sites. Soil water from the superficial soil layers was isotopically enriched compared with the deeper layers whose soil water $\delta 180$ values similar to those of the groundwater. Isotopic compositions of groundwater were generally constant with insignificant decrease in August. In 
April, June and August, soil water isotopic signatures in the $0-40 \mathrm{~cm}$ profile fluctuated considerably. In July, isotopic compositions of soil water above $220 \mathrm{~cm}$ were close to the recent rainfall, indicating the infiltration depth of rainwater and significant effect of recent precipitation on the soil water isotopic compositions (Fig. 6).
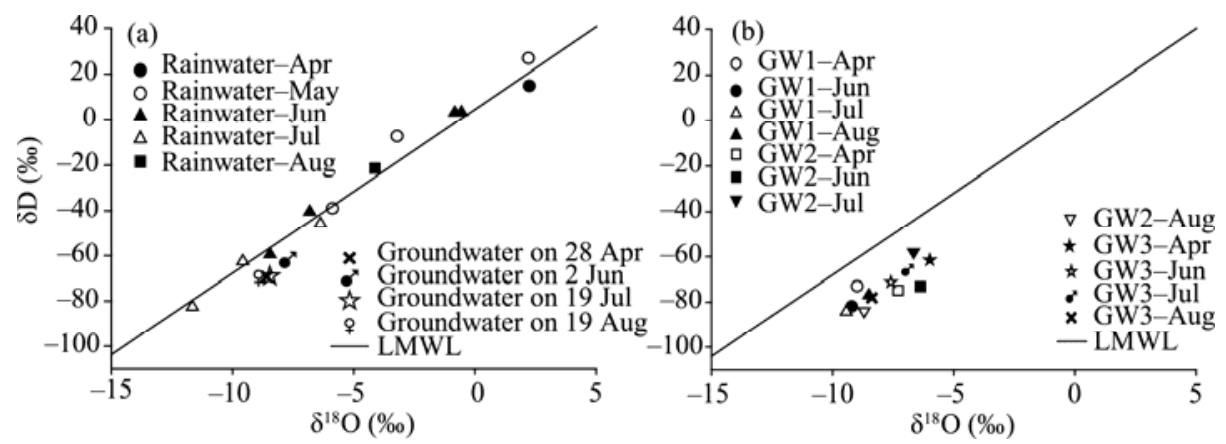

Fig. $4 \delta^{18} \mathrm{O}$ and $\delta \mathrm{D}$ of rainwater, groundwater (a) and plant xylem sap (b) and their relationship with Yinchuan local meteoric water line (LMWL) $\left(\delta \mathrm{D}=7.218 \delta^{18} \mathrm{O}+5.505\right.$; Liu et al., 2012). This function between $\delta \mathrm{D}$ and $\delta^{18} \mathrm{O}$ was established according to the values of $\delta \mathrm{D}$ and $\delta^{18} \mathrm{O}$ of rainwater collected and analyzed during the period from 1988 to 1992 in Yinchuan meteorological station $\left(38^{\circ} 48^{\prime} \mathrm{N}, 106^{\circ} 21^{\prime} \mathrm{E}\right)$, which belongs to Global Network of Isotopes in Precipitation (GNIP). GW1, GW2 and GW3 represent three slope positions with an increased groundwater depth.

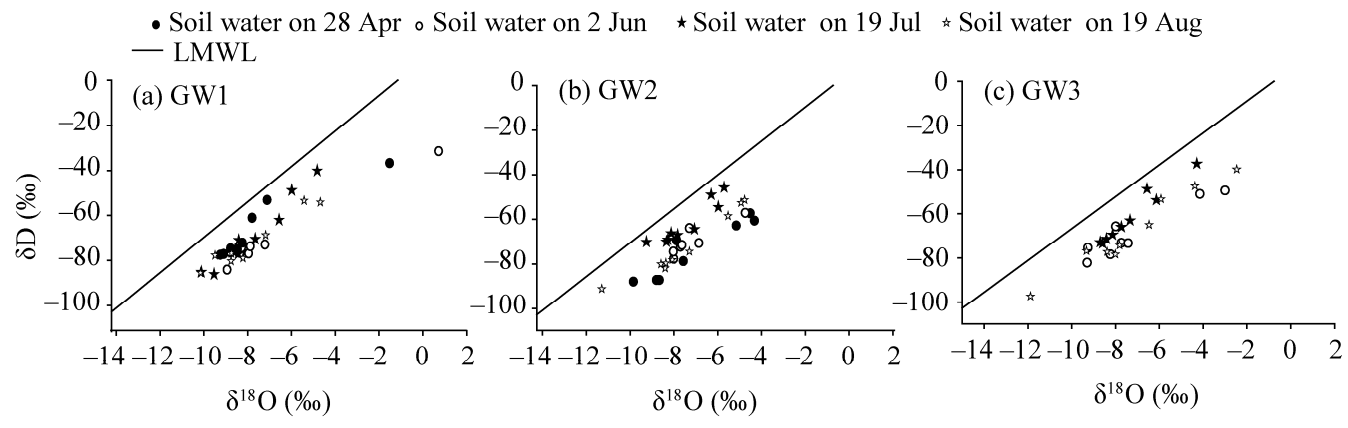

Fig. 5 Hydrogen and oxygen isotopic compositions of soil water and their relationship with local meteoric water line (LMWL) of Yinchuan $\left(\delta \mathrm{D}=7.218 \delta^{18} \mathrm{O}+5.505\right.$; Liu et al., 2012)

\subsection{Soil water condition and water uptake pattern along the topographic gradient}

There was a significant difference in water content in surface soil layers $(0-20 \mathrm{~cm})$ among different sampling times $(P<0.01)$ and slope positions $(P<0.05)$. The soil moisture was significantly higher at GW1 compared with the higher positions in April $(P<0.05)$, June $(P<0.01)$ and July $(P<0.01)$, which was associated with the significant difference in groundwater table between the three slope positions. Highest water content in surface layers $(0-20 \mathrm{~cm})$ was noted in July compared with April, June and August. High rainfall in July reduced the difference in the soil moisture between different slope positions in August. The soil water content from middle layers $(20-350 \mathrm{~cm})$ significantly differed among different slope positions $(P<0.001)$ but did not differ among different sampling times. In all sampling times, water content was higher in deep layer below $350 \mathrm{~cm}$ than in the shallower soil layers $(P<0.01)$ (Fig. 7).

Higher water uptake rate from deep soil layer $(>350 \mathrm{~cm})$, ranging from $68 \%$ to $80 \%$, was found for lucerne grown at GW1 compare with the other two slope positions in April, June and July. The lucernes grown at GW2 and GW3 displayed similar water utilization pattern in April and did not differ in the water uptake depth. In June, lucerne at GW2 mainly acquired their water from middle 

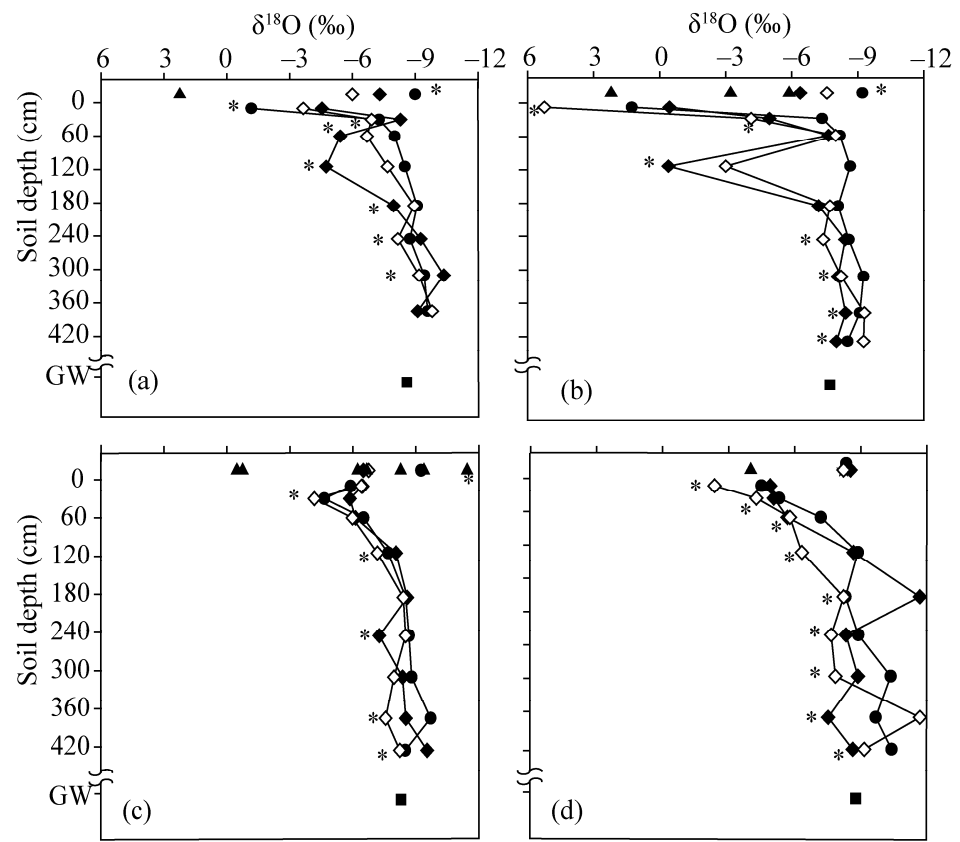

-- Soil water-GW1 $\diamond-$ Soil water-GW

$\multimap$ Soil water-GW2 - Groundwater

$\bullet$ Plant xylem water-GW2 $\diamond$ Plant xylem water-GW3

- Plant xylem water-GW1 $\triangle$ Rainwater

Fig. $6 \delta^{18} \mathrm{O}$ of soil water, groundwater, plant stem xylem sap and rainwater in Beiwangjuan village on 28 April (a), 2 June (b), 19 July (c) and 19 August (d). ${ }^{*}$ indicates statistically significant difference between different slopes at $\alpha=0.05$.

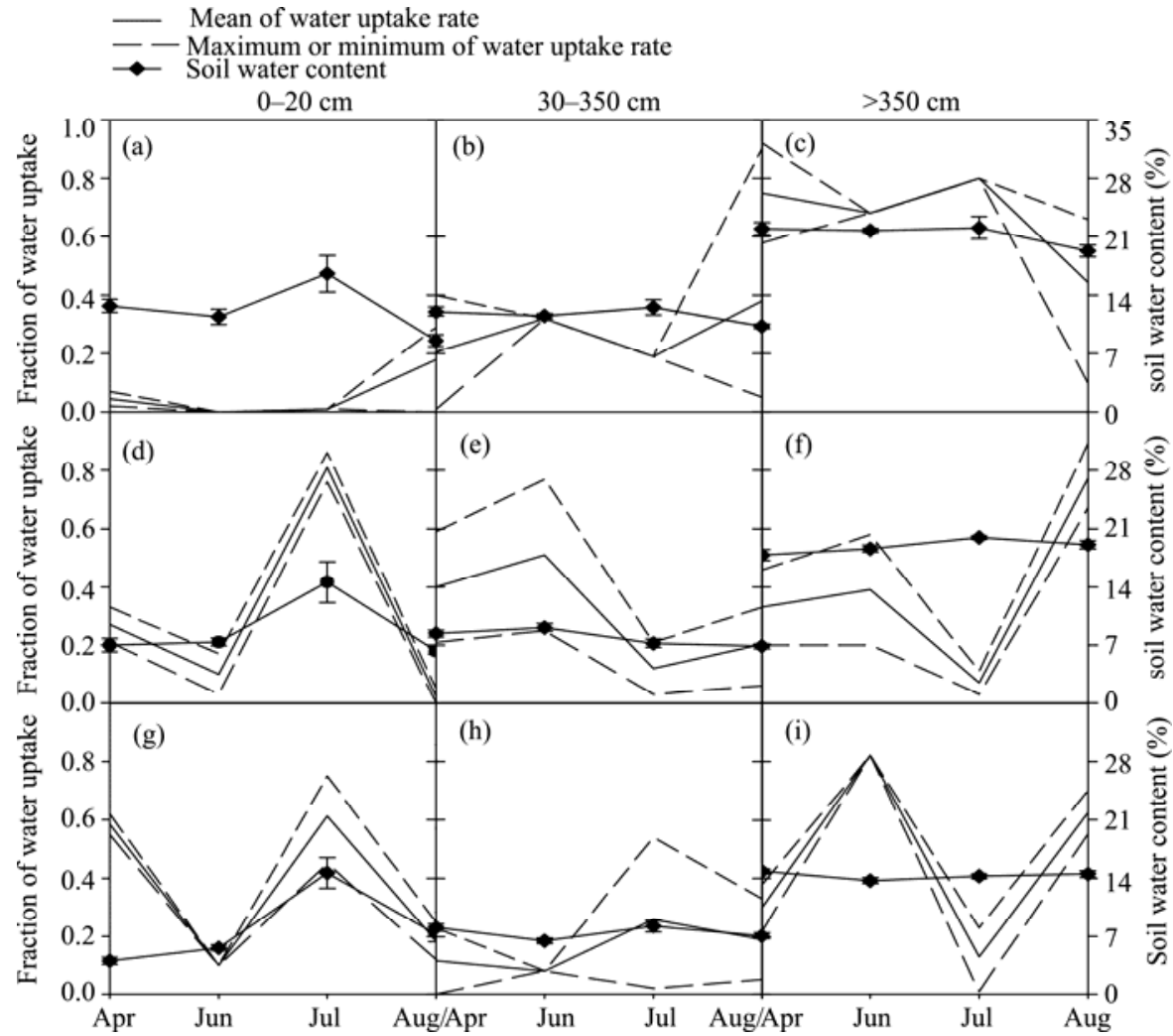

Fig. 7 Fraction of water uptake from surface soil layer $(0-20 \mathrm{~cm})$, middle soil layer $(20-350 \mathrm{~cm})$ and deep soil layer $(350-450 \mathrm{~cm})$ at GW1 $(\mathrm{a}-\mathrm{c})$, GW2 $(\mathrm{d}-\mathrm{f})$ and GW3 $(\mathrm{g}-\mathrm{i})$ sites for lucerne calculated by the mixing IsoSource model 
and deep layers with water uptake rate of 51\% and 39\%; while lucerne at GW3 mostly used water from deep layer with water uptake rate of $82 \%$. In July, highest water uptake rates from surface layers, up to $81.0 \%$ and $61.3 \%$, were found for the lucernes at GW2 and GW3, which was consistent with high water content resulting from high rainfall, occurred in July. In August, the lucernes at GW2 and GW3 turned to absorb water from deep layer (water uptake rates being $77.3 \%$ and $62.5 \%$ respectively) (Fig. 7).

\subsection{Agronomic and physiological characters along the topographical gradient}

For the two cuttings completed on 2 June and 19 August, significantly higher $(P<0.05)$ above-ground biomass of lucerne was observed in lower position plots than in upper position plots. There were also significant differences in biomass and plant height between different cuttings $(P<0.05)$ (Table 2).

Table 2 Comparison on the yield and plant height of lucernes in three sites in Beiwangjuan village

\begin{tabular}{|c|c|c|c|c|c|c|c|}
\hline \multirow[b]{2}{*}{ Item } & \multirow[b]{2}{*}{ Cutting } & \multicolumn{3}{|c|}{ Slope position } & \multicolumn{3}{|c|}{$F$-test } \\
\hline & & GW1 & GW2 & GW3 & $\begin{array}{l}\text { Cutting } \\
(\mathrm{C}, d f=1)\end{array}$ & $\begin{array}{c}\text { Slope position } \\
(\mathrm{S}, d f=2)\end{array}$ & $\begin{array}{l}\mathrm{C} \times \mathrm{S} \\
(d f=2)\end{array}$ \\
\hline \multirow{2}{*}{$\begin{array}{l}\text { Biomass } \\
\left(\mathrm{kg} / \mathrm{hm}^{2}\right)\end{array}$} & $\begin{array}{l}\text { Cutting } 1 \\
\text { ( } 2 \text { June) }\end{array}$ & $1,368.60 \pm 89.24^{\mathrm{aB}}$ & $1,039.95 \pm 122.26^{\mathrm{bB}}$ & $928.85 \pm 241.05^{\mathrm{bA}}$ & \multirow{2}{*}{$260.57^{* *}$} & \multirow{2}{*}{$52.96^{* *}$} & \multirow{2}{*}{$8.33^{*}$} \\
\hline & $\begin{array}{l}\text { Cutting } 2 \\
\text { (19 August) }\end{array}$ & $1,933.85 \pm 40.66^{\mathrm{aA}}$ & $1,885.80 \pm 116.39^{\mathrm{aA}}$ & $1,401.25 \pm 88.32^{\mathrm{bA}}$ & & & \\
\hline \multirow{2}{*}{$\begin{array}{l}\text { Plant height } \\
\text { (cm) }\end{array}$} & $\begin{array}{l}\text { Cutting } 1 \\
\text { ( } 2 \text { June) }\end{array}$ & $48.67 \pm 1.53^{\mathrm{aB}}$ & $47.00 \pm 3.61^{\mathrm{aB}}$ & $43.00 \pm 5.29^{\mathrm{aB}}$ & \multirow{2}{*}{$86.00^{* *}$} & \multirow{2}{*}{$6.34^{*}$} & \multirow{2}{*}{0.114} \\
\hline & $\begin{array}{l}\text { Cutting } 2 \\
\text { (19 August) }\end{array}$ & $63.33 \pm 1.64^{\mathrm{aA}}$ & $63.00 \pm 2.65^{\mathrm{aA}}$ & $57.00 \pm 4.36^{\mathrm{aA}}$ & & & \\
\hline
\end{tabular}

Note: Different capital letters and lowercases represent significant differences among different cutting times and different slope positions at $P<0.05$ level, respectively. ${ }^{*}$ and ${ }^{* *}$ indicate the significance at $P<0.05$ and $P<0.01$ levels, respectively.

The lucernes grown at lower positions displayed higher values of stomatal conductance (in June), $\Delta^{13} \mathrm{C}$ (in April, June and August) and predawn xylem sap potential (in four sampling times) compared with those grown at upper positions (Fig. 8).
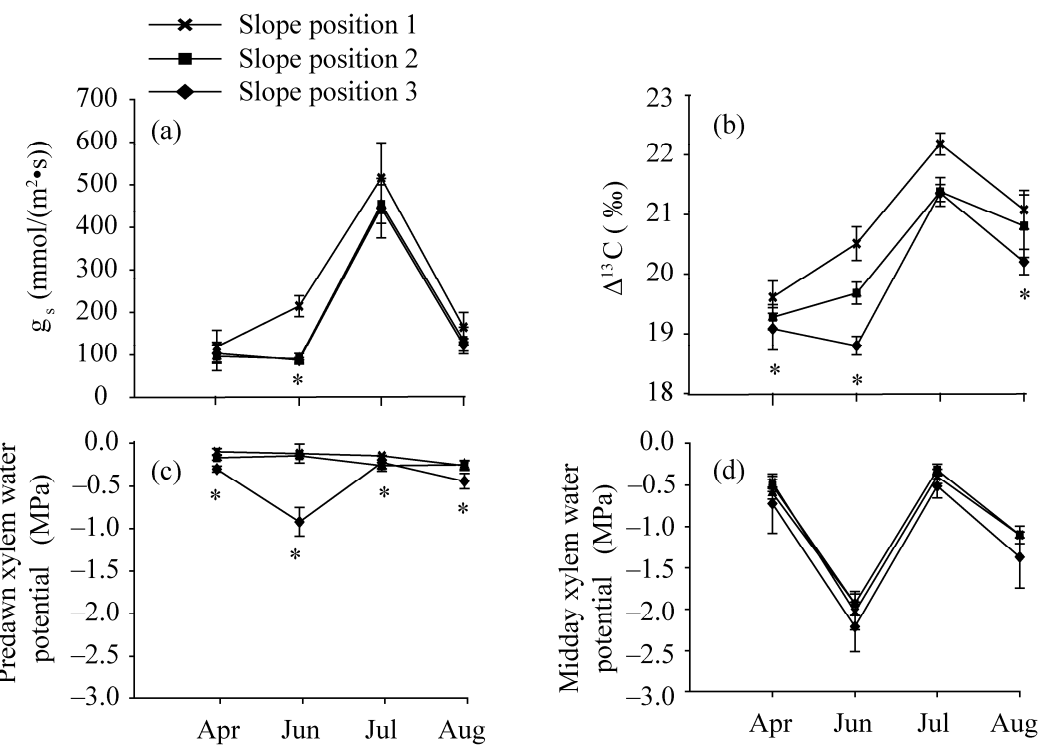

Fig. 8 Leaf stomatal conductance $\left(g_{s} ; a\right)$, carbon isotope discrimination $\left(\Delta^{13} C\right)$ of whole plant (b), xylem sap potential $(\psi)$ in predawn (c) and midday (d) for lucerne grown at three slope positions. * indicates significant differences between slope positions within a sampling date at $P<0.05$ level. 


\section{Discussion}

\subsection{Sources of soil water}

Using stable isotopes to determine the water sources for plant transpiration depends on variation in the isotopic compositions of different endpoints (Eggemeyer et al., 2009). In this study, we observed a vertical gradient in soil water $\delta^{18} \mathrm{O}$ profiles. The $\delta \mathrm{D}$ and $\delta^{18} \mathrm{O}$ values of groundwater, soil water and plant xylem sap fell to the right side of LMWL in Northwest China, with the coordinates $\left(\delta \mathrm{D}\right.$ versus $\left.\delta^{18} \mathrm{O}\right)$ of soil water from shallow layers plotted far away from the lines, indicating strong evaporation enrichment effect. As shown in this result, there is an isotopic enrichment (i.e. enriched in heavy isotopes, ${ }^{18} \mathrm{O}$ and ${ }^{2} \mathrm{H}$ ) of soil water from the surface layer due to evaporation, which is consistent with other reports (Eggemeyer et al., 2009; Saha et al., 2009; Zhu et al., 2014). The values of groundwater isotopic compositions were relatively low and varied insignificantly during the study period, implying the groundwater experienced less evaporation, with $\delta \mathrm{D}$ and $\delta^{18} \mathrm{O}$ plotted closed to the LMWL in arid region of Northwest China.

Significant difference in the $\delta^{18} \mathrm{O}$ signatures of soil water, plant xylem sap and soil water content along the elevation gradient was observed (Fig. 6). Soil water and plant xylem sap from the higher slope positions (GW2 and GW3) had more positive isotopic compositions, which might be attributed to the less recharge of groundwater (isotopically depleted) as a result of higher elevation and coarser soil texture. At these slope positions, it is difficult for groundwater to move up to the upper layer via soil capillary as a consequence of more proportion of sand or silt in the superficial and medium soil profile (Table 1). Thus, intensified evaporation in the surface soil layers led to enrichment in the hydrogen and oxygen isotopes of soil water. Conversely, the soil profile at lower slope position (GW1) was characterized by high moisture content and more negative isotopic composition. This can also be explained by more recharge from groundwater to the superficial layer attributed to shallower groundwater table and stronger capillary effect derived from higher clay fraction in the soil profile.

The temporal variation in the isotopic compositions of rainwater had significant effect on the soil isotopic composition profile. Soil water was isotopically enriched in 80-150 cm layers at GW2 and GW3 in June and depleted in 150-220 cm at GW2 and in 350-400 cm layers at GW3 in August (Fig. 6). This phenomenon might be explained by the "preferential flow" which is attributed to macropore flow, consisting of either cracks and fissures or biopores such as earthworm burrows and root channels (Bundt et al., 2001). In this study, high sand fraction in 0-20 $\mathrm{cm}$ at GW2 and in $0-300 \mathrm{~cm}$ soil profile at GW3 would form preferential flow paths leading to the rapid infiltration of upper soil water which derived from the isotopically enriched or depleted rain fell previously (Fig. 6). The movement of soil water vertically would recompose the soil isotopic profile by replacement of "old soil water" with new infiltrating water (Tang and Feng, 2001; Eggemeyer et al., 2009; Zhu et al., 2014), resulting in abrupt changes in isotopic compositions in some layers. Presumably, the isotopic-enriched rainwater precipitated during the late May would move from upper layers downwards, which resulted in an increase in the isotopic compositions in a certain soil layer. On the contrary, the frequent rain (with isotopic-depleted ranging from $-6.38 \%$ to $-11.67 \%$ ) events occurred in July led to significant decrease in isotopic compositions in upper soil layers in July and in some deep soil layers in the subsequent month. In GW1, negligible variation in the $\delta^{18} \mathrm{O}$ values of soil water from layers below $180 \mathrm{~cm}$ over time implied the infiltration depth of rainwater. In the Loess Plateau of northern China, the reported recharge depth by rain infiltration ranged from 70 to $300 \mathrm{~cm}$ according to the annual precipitation and 138 $\mathrm{cm}$ on average for a 16-year study period (Li and Huang, 2008; Fan et al., 2014). In this study, non-significant increase in soil water content below $180 \mathrm{~cm}$ (data not shown) supported this inference.

\subsection{Plant water uptake patterns along the topographical gradient}

Steady and high dependence on water from deeper soil layers $(>350 \mathrm{~cm})$ was found for the lucerne grown in slope position 1 (GW1). This was related to higher soil moisture below $350 \mathrm{~cm}$ which might be recharged by shallow groundwater, in agreement with the previous reports (York et al., 2002; Zencich et al., 2002; Chen and Hu, 2004, Yeh and Eltahir, 2005; O'Grady et al., 2006, Xu 
and $\mathrm{Li}, 2006$ ). Thorburn et al. (1993) reported that capillary rise could recharge soils to within 0.5 $\mathrm{m}$ of the soil surface from a water table at least $3 \mathrm{~m}$ deep at an Australian study site (Thorburn et al., 1993). Because our study site is located at the transitional zone between the Mu Us Desert and the loess hilly area (Loess Plateau) which is rich in groundwater resource with shallow table (Wang et al., 2013), higher water content and more negative values of soil water $\delta \mathrm{D}$ and $\delta^{18} \mathrm{O}$ below $150 \mathrm{~cm}$ at GW1 must be related with the significant recharge of groundwater to the soil profile.

It is well agreed that lucerne has a high ET rate and deep roots than annual pastures and crops (Blad and Rosenberg, 1976; Ward et al., 2002; Fan et al., 2014). Lucerne was observed to be able to develop root deeper than $5 \mathrm{~m}$ in two years and deeper than $10 \mathrm{~m}$ after five years (Jia et al., 2006; Li and Huang, 2008; Shen et al., 2009). Several studies conducted in arid and semi-arid regions have reported that groundwater is an important water source for plants due to the lack of reliable surface water resources (Flanagan and Ehleringer, 1991; Yin et al., 2011). According to our observation, the depth of groundwater in different slope position ranges from 3.7 to $8.3 \mathrm{~m}$ (Table 1). Under this circumstance, it is not difficult for lucerne to develop root access to the aquifer or the capillary fringe of groundwater. In this study, higher groundwater utilization rate for lucerne grown in lower slope position may be attributed to either easy access for lucerne's root to the capillary fringe of groundwater or the recharge of groundwater to the upper soil profile available for the growth of lucerne.

The water uptake patterns of lucerne in upper slope positions were related to the temporal fluctuation in rainfall which affected the vertical distribution of soil water in the soil profile. Some previous studies also reported that many species exhibited a shift in water use from a dominantly deep water source (e.g. groundwater) during the dry period to a dominantly shallow water source (soil water) during the wet period (Dawson and Pate, 1996; McCole and Stern, 2007). In this study, the lucernes in slope positions 2 and 3 depended mostly on water from deep soil layers during dry period (June and August), and turned to use surface water in July when abundant rain occurred, implying a flexible water uptake pattern for lucerne grown in fluctuating soil water conditions.

Higher biomass, stomatal conductance $\left(g_{s}\right)$ and stem water potentials in slope position 1 compared with the upper positions reflect better leaf water status for lucerne grown in low position. This finding is reinforced by measurement of whole plant $\Delta^{13} \mathrm{C}$ that provided a relevant indicator of time-integrated leaf function. In $\mathrm{C}_{3}$ plant, $\Delta^{13} \mathrm{C}$ positively correlated with $\mathrm{C}_{\mathrm{i}} / \mathrm{C}_{\mathrm{a}}$ (the ratio of internal leaf $\mathrm{CO}_{2}$ concentration to ambient $\mathrm{CO}_{2}$ concentration) (Farquhar and Richards, 1984; Ehdaie et al., 1991; Johnson and Bassett, 1991; Zhu et al., 2010). In this study, whole plant $\Delta^{13} \mathrm{C}$ values highly and positively associated with soil water condition in different slope positions and measuring periods, which is consistent with the theory above. $\Delta \Delta^{13} \mathrm{C}$ of lucerne at GW1 was significantly higher than that at GW2 or GW3 in April, June and August (Fig. 8), implying much more groundwater used by lucerne in lower positions and the water stress was released, while the lucerne in upper positions experienced intensified water stress.

However, as for the negative association of $\Delta^{13} \mathrm{C}$ with water use efficiency (WUE) (Farquhar and Richards, 1984; Ehdaie et al., 1991), lucerne grown at GW1 would has lower WUE than those at GW2 or GW3 and transpired more per unit of dry matter produced. Considering the evapotranspiration of lucerne is larger than annual precipitation in semiarid region, irrational planting lucerne without irrigation in the low slope position could accelerate the soil water and groundwater exhaust by transpiration leading to decrease in the groundwater table. Given the amount of minable groundwater is only $1.8 \times 10^{7} \mathrm{~m}^{3} / \mathrm{a}$ in Yanchi county, Ningxia (Li et al., 2004), the planting of lucerne must be controlled within a reasonable scale in terms of area and sowing density. In addition, the integration of lucerne with annual cropping systems is also a solution to make optimal use of soil water across rotation (Shen et al., 2009). In lower rainfall environments, such as central area in Ningxia, it is important to terminate lucerne growth early enough to avoid water deficit. Shen et al. (2009) suggested that five to six years might be a suitable period for growing lucerne on slope-land in a $380 \mathrm{~mm}$ rainfall environment.

Prospectively, the study on water cycle of lucerne grassland should not be limited to determine the water sources at individual level as demonstrated in this work. Study on the water flux of 
lucerne grassland is essential for better understanding its role in the water balance of the localized ecosystem. The future researches should be concentrated on the accurate estimate of ET on lucerne pastures and partitioning of ET into its components, taking advantage of stable isotopes methods which offer great promise for partitioning the ET flux at the ecosystem scale (Yepez et al., 2003).

\section{Conclusions}

The $\delta \mathrm{D}$ and $\delta^{18} \mathrm{O}$ values of groundwater, soil water and plant xylem sap fell to the right side of the arid Northwest China local meteoric water line (ANC LMWL), with soil water from shallow layer isotopically enriched and groundwater depleted. Soil water from superficial soil layers experienced intensified evaporation because of the semi-arid climate in this area. For the three slope positions, the values of $\delta^{18} \mathrm{O}$ and $\delta \mathrm{D}$ decreased and the soil moisture content increased as the elevation decreased. Significant contribution of water from deep soil layers and groundwater to the growth of lucerne grown in the slope position 1 resulted in better plant water status and growth performance during the whole sampling period. The lucernes in slope position 2 and 3 depended mostly on water from deep soil layers and groundwater during dry period-June and August, and turned to use surface water in July when the highest rain occurred, indicating the flexible water use strategy of lucerne in line with the temporal fluctuation in rainfall.

In the Ningxia semi-arid area without irrigation condition, lucerne pasture is suggested to be established in area with shallow groundwater depth so as to obtain better yield performance, higher ecological and economic returns. Nevertheless, suitable length of lucerne phase and rotation with annual crops should be studied to avoid the exhaustion of groundwater.

\section{Acknowledgements}

This study was funded by the National Natural Science Foundation of China (31160478), the National Program on Key Basic Research Project of China (2012CB723206) and the Agricultural Breeding Project of Ningxia Hui Autonomous Region (2014NYYZ0401). We all appreciate the Yanchi Scientific and Technical Division for supplying geographical information of experimental sites.

\section{References}

Asbjornsen H, Shepherd G, Helmers M, et al. 2008. Seasonal patterns in depth of water uptake under contrasting annual and perennial systems in the Corn Belt Region of the Midwestern U.S. Plant and Soil, 308(1-2): 69-92.

Bauder J W, Bauer A, Ramirez J M, et al. 1978. Alfalfa water use and production on dryland and irrigated sandy loam. Agronomy Journal, 70(1): 95-99.

Blad B L, Rosenberg N J. 1976. Evaluation of resistance and mass transport evapotranspiration models requiring canopy temperature data. Agronomy Journal, 68(5): 764-769.

Bundt M, Widmer F, Pesaro M, et al. 2001. Preferential flow paths: biological 'hot spots' in soils. Soil Biology and Biochemistry, 33(6): 729-738.

Chen X, Hu Q. 2004. Groundwater influences on soil moisture and surface evaporation. Journal of Hydrology, 297(1-4): 285-300.

Chimner R A, Cooper D J. 2004. Using stable oxygen isotopes to quantify the water source used for transpiration by native shrubs in the San Luis Valley, Colorado U.S.A. Plant and Soil, 260(1-2): 225-236.

Dawson T. 1993. Water sources of plants as determined from xylem-water isotopic composition: perspectives on plant competition, distribution, and water relations. In: Ehleringer J R, Hall A E, Farquhar G D. Stable Isotopes and Plant Carbon-water Relations. San Diego: Academic Press Inc, 465-496.

Dawson T E, Ehleringer J R. 1993. Isotopic enrichment of water in the "woody" tissues of plants: implications for plant water source, water uptake, and other studies which use the stable isotopic composition of cellulose. Geochimica et Cosmochimica Acta, 57(14): 3487-3492.

Dawson T E, Pate J S. 1996. Seasonal water uptake and movement in root systems of Australian phraeatophytic plants of dimorphic root morphology: a stable isotope investigation. Oecologia, 107(1): 13-20.

Dunin F X, Smith C J, Zegelin S J, et al. 2001. Water balance changes in a crop sequence with Lucerne. Crop \& Pasture Science, 52(2): 247-261. 
Eggemeyer K D, Awada T, Harvey F E, et al. 2009. Seasonal changes in depth of water uptake for encroaching trees Juniperus virginiana and Pinus ponderosa and two dominant $\mathrm{C}_{4}$ grasses in a semiarid grassland. Tree Physiology, 29(2): 157-169.

Ehdaie B, Hall A E, Farquhar G D, et al. 1991. Water-use efficiency and carbon isotope discrimination in wheat. Crop Science, 31(5): 1282-1288.

Fan J, Gao Y, Wang Q J, et al. 2014. Mulching effects on water storage in soil and its depletion by alfalfa in the Loess Plateau of northwestern China. Agricultural Water Management, 138: 10-16.

Farquhar G D, Richards R A. 1984. Isotopic composition of plant carbon correlates with water-use efficiency of wheat genotypes. Australian Journal of Plant Physiology, 11(6): 539-552.

Flanagan L B, Ehleringer J R. 1991. Stable isotope composition of stem and leaf water: applications to the study of plant water use. Functional Ecology, 5(2): 270-277.

Han J C, Liu Y S, Luo L T. 2012. Research on the core technology of remixing soil by soft rock and sand in the Maowusu sand land region. China Land Science, 26(8): 87-94. (in Chinese)

Horton J L, Hart S C, Kolb T E. 2003. Physiological condition and water source use of Sonoran Desert riparian trees at the Bill Williams River, Arizona, USA. Isotopes in Environmental and Health Studies, 39(1): 69-82.

Jia Y, Li F M, Wang X L, et al. 2006. Soil water and alfalfa yields as affected by alternating ridges and furrows in rainfall harvest in a semiarid environment. Field Crops Research, 97(2-3): 167-175.

Jia Y, Li F M, Zhang Z H, et al. 2009. Productivity and water use of alfalfa and subsequent crops in the semiarid Loess Plateau with different stand ages of alfalfa and crop sequences. Field Crops Research, 114(1): 58-65.

Jia Y H, Shao M A. 2014. Dynamics of deep soil moisture in response to vegetational restoration on the Loess Plateau of China. Journal of Hydrology, 519: 523-531.

Johnson R C, Bassett L M. 1991. Carbon isotope discrimination and water use efficiency in four cool-season grasses. Crop Science, 31(1): 157-162.

Latta R A, Blacklow L J, Cocks P S. 2001. Comparative soil water, pasture production, and crop yields in phase farming systems with Lucerne and annual pasture in Western Australia. Crop \& Pasture Science, 52(2): 295-303.

Li F M, Zhang Z W. 1991. The study on water use of the alfalfa grassland and the Stipa bungeana grassland in Ningxia Yanchi. Acta Phytoecologica et Geobotanica Sinica, 15(4): 319-329. (in Chinese)

Li M, Su X X, Pan Z L. 2004. Counterplan and present condition of drinking water in Yanchi county of Ningxia. Ningxia Engineering Technology, 3(4): 395-397. (in Chinese)

Li Y S, Huang M B. 2008. Pasture yield and soil water depletion of continuous growing alfalfa in the Loess Plateau of China. Agriculture, Ecosystems \& Environment, 124(1-2): 24-32.

Liu H W, Xu M, Guan Q H. 2012. Variation characteristics and influencing factors of hydrogen-oxygen stable isotope in precipitation of Yinchuan area. Water Sciences and Engineering Technology, (1): 88-90. (in Chinese)

McCole A A, Stern L A. 2007. Seasonal water use patterns of Juniperus ashei on the Edwards Plateau, Texas, based on stable isotopes in water. Journal of Hydrology, 342(3-4): 238-248.

O'Grady A P, Eamus D, Cook P G, et al. 2006. Groundwater use by riparian vegetation in the wet-dry tropics of northern Australia. Australian Journal of Botany, 54(2): 145-154.

Phillips D L, Newsome S D, Gregg J W. 2005. Combining sources in stable isotope mixing models: alternative methods. Oecologia, 144(4): 520-527.

Raza A, Friedel J K, Moghaddam A, et al. 2013. Modeling growth of different Lucerne cultivars and their effect on soil water dynamics. Agricultural Water Management, 119(1): 100-110.

Ridley A M, Christy B, Dunin F X, et al. 2001. Lucerne in crop rotations on the Riverine Plains. 1. The soil water balance. Crop \& Pasture Science, 52(2): 263-277.

Romero-Saltos H, da S L Sternberg L, Moreira M Z, et al. 2005. Rainfall exclusion in an eastern Amazonian forest alters soil water movement and depth of water uptake. American Journal of Botany, 92(3): 443-445.

Rossatto D R, de Carvalho Ramos Silva L, Villalobos-Vega R, et al. 2012. Depth of water uptake in woody plants relates to groundwater level and Vegetation structure along a topographic gradient in a Neotropical savanna. Environmental and Experimental Botany, 77: 259-266.

Saha A K, da Silviera Lobo O’Reilly Sternberg L, Miralles-Wilhelm F. 2009. Linking water sources with foliar nutrient status in upland plant communities in the Everglades National Park, USA. Ecohydrology, 2(1): 42-54.

Shafroth P B, Stromberg J C, Patten D T. 2000. Woody riparian vegetation response to different alluvial water table regimes. Western North American Naturalist, 60(1): 66-76.

Shen Y Y, Li L L, Chen W, et al. 2009. Soil water, soil nitrogen and productivity of Lucerne-wheat sequences on deep silt loams in a summer dominant rainfall environment. Field Crops Research, 111(1-2): 97-108. 
Soylu M E, Kucharik C J, Loheide II S P. 2014. Influence of groundwater on plant water use and productivity: development of an integrated ecosystem-variably saturated soil water flow model. Agricultural and Forest Meteorology, 189-190: 198-210.

Tang K L, Feng X H. 2001. The effect of soil hydrology on the oxygen and hydrogen isotopic compositions of plants' source water. Earth and Planetary Science Letters, 185(3-4): 355-367.

Thorburn P J, Walker G R, Ehleringer J, et al. 1993. The source of water transpired by Eucalyptus camaldulensis: soil, groundwater, or streams?. In: Ehleringer J R, Hall A E, Farquhar G D. Stable Isotopes and Plant Carbon-Water Relations. San Diego, Calif., USA: Academic Press Limited Company, 511-527.

Wang L, Mu Y, Zhang Q F, et al. 2013. Groundwater use by plants in a semi-arid coal-mining area at the Mu Us Desert frontier. Environmental Earth Sciences, 69(3): 1015-1024.

Ward P R, Dunin F X, Micin S F. 2002. Water use and root growth by annual and perennial pastures and subsequent crops in a phase rotation. Agricultural Water Management, 53(1-3): 83-97.

West A G, Hultine K R, Sperry J S, et al. 2008. Transpiration and hydraulic strategies in a piñon-juniper woodland. Ecological Applications, 18(4): 911-927.

$\mathrm{Xu}$ D M, Wang K, Long S P. 2008. Vegetation characteristics and soil properties in the transitional zone in south fringe of Mu Us Sandy Land. Bulletin of Soil and Water Conservation, 28(5): 39-43, 47. (in Chinese)

Xu H, Li Y. 2006. Water-use strategy of three central Asian desert shrubs and their responses to rain pulse events. Plant and Soil, 285(1-2): 5-17.

Yeh P J F, Eltahir E A B. 2005. Representation of water table dynamics in a land surface scheme. Part II: subgrid variability. Journal of Climate, 18(12): 1881-1901.

Yepez E A, Williams D G, Scott R L, et al. 2003. Partitioning overstory and understory evapotranspiration in a semiarid savanna woodland from the isotopic composition of water vapor. Agricultural and Forest Meteorology, 119(1-2): 53-68.

Yin L H, Hou G C, Dou Y, et al. 2011. Hydrogeochemical and isotopic study of groundwater in the Habor Lake Basin of the Ordos Plateau, NW China. Environmental Earth Sciences, 64(6): 1575-1584.

York J P, Person M, Gutowski W J, et al. 2002. Putting aquifers into atmospheric simulation models: an example from the Mill Creek Watershed, northeastern Kansas. Advances in Water Resources, 25(2): 221-238.

Zencich S J, Froend R H, Turner J V, et al. 2002. Influence of groundwater depth on the seasonal sources of water accessed by Banksia tree species on a shallow, sandy coastal aquifer. Oecologia, 131(1): 8-19.

Zhang E Y, Shi Y C, Gao C R, et al. 2009. Regional geology and hydrogeology of the Yellow River basin. Bulletin of the Geological Survey of Japan, 60(1-2): 19-32.

Zhu L, Li S H, Liang Z S, et al. 2010. Relationship between yield, carbon isotope discrimination and stem carbohydrate concentration in spring wheat grown in Ningxia irrigation region (North-west China). Crop and Pasture Science, 61(9): 731-742.

Zhu L, Wang Z H, Mao G L, et al. 2014. Water uptake from different soil depths for halophytic shrubs grown in Northern area of Ningxia plain (China) in contrasted water regimes. Journal of Plant Interactions, 9(1): 26-34. 